\title{
DÜBLIN
}

Technological University Dublin

ARROW@TU Dublin

Articles

School of Physics \& Clinical \& Optometric

Science

2012-10

\section{Characterisation of the Colour Doppler "Twinkle" Artefact}

Deirdre Cassidy

Technological University Dublin

Andrew Fagan

St. James's Hospital, Dublin

Jacinta Browne

Technological University Dublin, jacinta.browne@tudublin.ie

Follow this and additional works at: https://arrow.tudublin.ie/scschphyart

Part of the Biological and Chemical Physics Commons

\section{Recommended Citation}

Cassidy, D., Browne, J., Fagan, G. : Characterisation of the Colour Doppler "Twinkle" Artefact. Physica Medica, Vol. 28, no. 4, 2012, p. 333-334. doi:10.1016/j.ejmp.2012.06.012

This Article is brought to you for free and open access by the School of Physics \& Clinical \& Optometric Science at ARROW@TU Dublin. It has been accepted for inclusion in Articles by an authorized administrator of ARROW@TU Dublin. For more information, please contact arrow.admin@tudublin.ie, aisling.coyne@tudublin.ie, gerard.connolly@tudublin.ie.

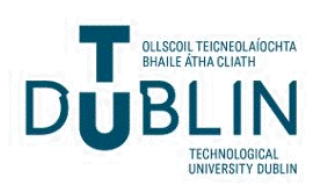




\section{Characterisation of the Colour Doppler "Twinkle" Artefact}

Deirdre Cassidy ${ }^{1}$, Andrew J. Fagan $^{2,3}$ \& Jacinta E. Browne ${ }^{1}$

${ }^{1}$ Medical Ultrasound Physics and Technology Group, School of Physics / FOCAS, Dublin Institute of Technology, Kevin's Street, Dublin 8, Ireland

${ }^{2}$ Centre for Advanced Medical Imaging, St. James's Hospital/Trinity College Dublin, Dublin 8, Ireland

${ }^{3}$ Medical Physics and Bioengineering, St. James's Hospital, Dublin 8, Ireland

This investigation involved the development of a range of Colour Doppler Twinkle Artefact phantoms to characterise and quantify the "Twinkle" artefact which is often present when an irregular structure is encountered in the imaged field of view. The artefact occurs in both colour and power Doppler ultrasound imaging and manifests as a false depiction of colour velocity information in stationary soft tissue and therefore can cause significant misdiagnosis of areas of flow within the patient. It has been hypothesised that it is generated due to a strongly reflecting medium composed of individual reflectors and therefore becomes a clinical concern when parenchymal calcifications are encountered. (Tsao et al, 2006)

The aim of this study was to investigate the occurrence and magnitude of this artefact across a range of ultrasound scanners and to monitor the effects on the artefact of varying image acquisition parameters.

A range of phantoms were produced that could reproducibly recreate the Twinkle artefact, the presence of which was quantified in a range of scanners (Zonare, Siemens Antares, Philips HDI and IU22). These phantoms included both fine and coarse structures as well as a flow channel in one of the phantoms, through which blood mimicking fluid was pumped. A semiquantitative grading system was implemented and instrument controls such as pulse repetition frequency (PRF), colour write priority, greyscale gain and depth of focal zone were varied in order to determine their impact on the Twinkle artefact.

Instrument control settings were found to significantly affect the intensity of this artefact, predominantly PRF showed a significant increase in the presence of this artefact. Furthermore, the extent of the artefact varied greatly across the range of scanners with Siemens Antaries and Zonare being most sensitive to the artefact.

The implication of this study has shown the Twinkle artefact to be dependent on scanner specifications and instrumental parameters. With careful image optimisation, a reduction or elimination of the artefact can be achieved.

Tsao, T.-F., Kang, R.-J., Tyan, Y.-S., Gueng, M.-K., Lee, T., \& Lee, S.-K. (2006). Color Doppler Twinkling Artifact Related to Chronic Pancreatitis with Parenchymal Calcification. Acta Radiologica, 47(6), 547-548. 